\title{
ANALISIS USAHA PENGOLAHAN SANTAN KELAPA DI KECAMATAN TEMBILAHAN KABUPATEN INDRAGIRI HILIR
}

\author{
Yolanda Sri Rahayu \\ Program Studi Agribisnis Fakultas Pertanian UNISI \\ Email: yolanda.srirahayu08@gmail.com
}

\begin{abstract}
ABSTRAK
Tujuan penelitian adalahuntuk mengetahui besar keuntungan yang diperoleh dari usaha pengolahan santan kelapa dan untuk mengetahui tingkat efisiensi usaha pengolahan santan kelapa di Kecamatan Tembilahan. Metode yang digunakan untuk menganalisis data dalam penelitian ini adalah dengan menggunakan alat analisis biaya, penerimaan, keuntungan, pendapatan kerja keluarga, dan efisiensi usaha.. Hasil penelitian menunjukkan bahwa total biaya pada usaha pengolahan santan kelapa yaitu biaya tidak tetap sebesar Rp.27.359.400,00 dan biaya tetap sebesar Rp.875.559,56 , rata - rata penerimaan yang diperoleh sebesar Rp. 35.033.200,00 per bulan, rata-rata keuntungan yang diperoleh adalah sebesar Rp.6.798.240,44 per bulan, dan rata - rata pendapatan kerja keluarga sebesar Rp. 8.688.000,00 per bulan (2) Nilai RCR adalah sebesar 1,23 yang berarti usah apengolahan santan kelapa efesien.
\end{abstract}

Kata kunci : santan kelapa, penerimaan, keuntungan, efisiensi

\section{PENDAHULUAN}

Perkebunan kelapa di Kabupaten Indragiri Hilir memiliki produksi yang besar di Provinsi Riau, karena hampir semua petani di Kabupaten Inhil berkebun kelapa sehingga banyak produk yang berbahan baku kelapa. Kelapa merupakan salah satu anggota tanaman palmae yang paling dikenal dan banyak tersebar di daerah tropis. Kelapa memiliki berbagai macam produk turunan seperti gula kelapa, minyak goreng, nata de coco, santan kelapa, dan lainnya. Buah kelapa dapat dimanfaatkan mulai dari luar hingga dalam kelapa. Daging kelapa biasanya diolah menjadi santan sebagai campuran untuk berbagai makanan yang mencirikan masakan khas Indonesia.
Santan kelapa merupakan air perahan dari kelapa tua yang diperas. Santan mempunyai rasa lemak dan digunakan sebagai perasa yang menyedapkan makanan, yang fungsinya belum dapat digantikan oleh bahan lain karen citra dan aroma yang ditimbulkan sangat khas, sehingga akan mempengaruhi citra masakan yang diolah. Menurut Santoso (2000), santan adalah hasil olahan kelapa yang paling banyak penggunaannya di masyarakat Indonesia. Disamping untuk konsumsi dalam negeri, santan diekspor dalam bentuk awetan yaitu santan kelapa beku dan santan bubuk. Santan luas penggunaannya terutama untuk bahan berbagai masakan rumah tangga sehari - hari, industri kue, roti, es krim, makanan- 
makanan tradisional dan lain sebagainya.

Permintaan santan kelapa di Kecamatan Tembilahan Kabupaten Indragiri Hilir cukup banyak apalagi untuk skala industri rumah makan yang ada disekitar Kecamatan Tembilahan ditambah dengan permintaan-permintaan rumah tangga lainnya. Maka dari itu cukup banyak masyarakat yang melakukan usaha pengolahanan santan.Selain itu walaupun harga kelapa naik, usaha pengolahan santan kelapa kian berkembang dari tahun ke tahun. Pengolahan kelapa menjadi santan kelapa tidaklah begitu sulit, para pengolah hanya membelah kelapa dan memisahkan daging kelapa dari batoknya saja, lalu setelah itu daging kelapa dimasukkan kedalam mesin parut, setelah daging kelapa diparut barulah parutan kelapa dimasukin ke dalam mesin yang akan memisahkan ampas kelapa dengan santannya. Inilah yang pada dasarnya membuat para produsen pedagang atau pengolah santan kelapa untuk melirik usaha pengolahan santan kelapa yang berbasis teknologi mesin selain permintaannya yang banyak, cara pengolahanya juga cukup cepat.

Analisis usaha sangat penting dilakukan bagi pedagang pengolah santan kelapa dalam melakukan usahanya guna peningkatan keuntungan serta pengembangan usaha.Maka diperlukan analisis mengenai keuntungan dan efisiensi dari industri pengolahan santan kelapa di Kecamatan Tembilahan. Berdasarkan latar belakang diatas maka tujuan dari penelitian ini adalah untuk mengetahui berapa besar keuntungan yang diperoleh dari usaha pengolahan santan kelapa dan untuk mengetahui tingkat efisiensi usaha pengolahan santan kelapa yang ada di Kecamatan Tembilahan Kabupaten Indragiri Hilir.

\section{TINJAUAN PUSTAKA \\ 2.1. Kelapa}

Tanaman kelapa adalah tumbuhan jenis palma-palmaan yang paling banyak tersebar di daerah tropis, tumbuhan ini dapat tumbuh pada ketinggian di atas permukaan laut dengan suhu optimum untuk pertumbuhan sekitar $27-28^{\circ} \mathrm{C}$. Tanaman kelapa berbuah setelah berusia 3-4 tahun. Buah kelapa yang normal terdiri dari beberapa bagian : yaitu sabut (eksokarp dan mesokarp), tempurung (endocarp), daging buah (endosperm) dan air kelapa. Minyak kelapa dihasilkan dari daging buah kelapa yang berwarna putih dan lunak (Ketaren, 1986).

Dari jenis spesies kelapa (cocos nucifera L) dikenal dua varietas utama yaitu varietas dalam (tall variety) dan varietas genjah (dwarf variety). Dengan adanya persilangan, terutama pada golongan varietas dalam terjadilah variasi yang cukup luas didalam varietas yang sama. Variasi ini dapat terjadi pada tinggi batang, warna, bentuk dan ukuran buah. Hal yang sama terjadi pula pada varietas genjah terutama pada warna kulit buahnya sehingga terjadilah warna hijau, kuning, dan merah kecoklatan. Hasil persilangan antara varietas dalam dan varietas genjah dikenal sebagai golongan ketiga yaitu kelapa hibrida (Djatmiko, 1994).

\subsection{Santan Kelapa}

Santan adalah cairan putih kental yang dihasilkan dari kelapa yang diparut dan kemudian diperas bersama air. Santan mempunyai rasa lemak dan digunakan sebagai perasa yang menyedapkan masakan menjadi 
gurih. Pengolahan kelapa menjadi santan kelapa menggunakan daging kelapa yang disebut putih lembaga (endosperm). Putih lembaga (endosperm) ini diambil dengan cara memisahkannya dengan tempurung (endocarp). Setelah endosperm terlepas dengan endocarp barulah setelah itu dimasukkan kedalam mesin yang akan memisahkan langsung antara santan kelapa dengan ampas kelapa. Dengan adanya mesin ini sangat menghemat waktu dalam pengolahan kelapa menjadi santan kelapa.

Santan banyak digunakan dalam masakan Indonesia seperti opor ayam, rendang, gudeg, soto, sayur lodeh, nasi uduk atau dalam berbagai macam kari seperti kari daun singkong misalnya. Apalagi dalam bulan Ramadhan, santan hampir selalu digunakan sebagai bahan untuk dessert khas puasa seperti kolak pisang, es cendol, es campur, es buah, bubur candil, bubur kacang hijau termasuk juga untuk kue-kue tradisional seperti kue talam, carabikang atau apem. Santan mempunyai rasa lemak, sehingga membuat rasa masakan menjadi lebih sedap dan gurih dengan aroma khas kelapa yang harum (adanya senyawa nonylmethylketone). Santan juga dikenal dalam berbagai masakan tradisional negara-negara kawasan Asia Pasifik seperti Thailand, India, Sri Lanka, Malaysia, Filipina, Hawai sampai Brazil. Bahkan saat ini banyak makanan etnik bersantan yang mulai disebarluaskan ke negara-negara Barat (Eropa dan Amerika) dan diterima dengan baik oleh para konsumen (Soekopitojo, 2014).

\subsection{Analisis Usahatani}

Suatu proses produksi dapat berjalan jika adanya faktor produksi dan sarana produksi. Menurut Daniel (2002), faktor produksi adalah faktor yang mutlak diperlukan dalam proses produksi, sedangkan sarana produksi adalah sarana yang dibutuhkan dalam faktor produksi. Faktor produksi pada usaha santan terdiri dari sewa kios, modal, tenaga kerja dan manajemen kerja, sementara sarana produksi usaha santan terdiri dari alat - alat produksi santan kelapa, Biaya produksi terdiri dari biaya tetap dan biaya variabel. Biaya tetap adalah biaya yang jumlahnya tidak bergantung pada perubahan jumlah produksi, misalnya biaya penyusutan peralatan. Biaya variabel adalah biaya yang dipengaruhi oleh kapasitas produksi. Semakin besar kapasitas produksi maka semakin besar biaya yang dibutuhkan dan sebaliknya (Suryani et al, 2005)

Biaya produksi menurut Mulyadi (1995) merupakan biayabiaya yang terjadi untuk mengolah bahan baku menjadi produk jadi yang siap untuk dijual. Biaya Produksi dapat meliputi unsur-unsur yaitu bahan baku atau bahan dasar termasuk bahan setengah jadi, bahan-bahan pembantu atau penolong, upah tenaga kerja, penyusutan peralatan produksi, uang, modal, sewa, biaya penunjang seperti biaya angkut, biaya listrik dan pajak.

Semakin banyak jumlah produk yang dihasilkan maupun semakin tinggi harga per unit produksi yang bersangkutan, maka penerimaan total yang diterima produsen akan semakin besar. Sebaliknya jika peoduk yang dihasilkan sedikit dan harganya rendah maka penerimaan total yang diterima produsen semakin kecil (Soejarmanto dan Riswan, 1994). 
Penerimaan total / pendapatan kotor adalah jumlah seluruh penerimaan dari hasil penjualan sejumlah produk (barang yang dihasilkan).

Menurut Lipsey et al (1990) keuntungan adalah selisih antara pendapatan yang diterima dari penjualan dengan biaya kesempatan dari sumberdaya yang digunakan. Menurut Soemarso (2004:245) keuntungan (Pendapatan bersih) adalah selisih lebih pendapatan atas beban sehubungan dengan usaha untuk memperoleh pendapatan tersebut selama periode tertentu.

\subsection{Efisiensi Usahatani}

Efisiensi menurut ekonomi terkait dengan penggunaan biaya. Metode yang paling efisien menurut ekonomi ialah metode yang paling kecil biayanya. Efisiensi menurut ekonomi tergantung pada harga harga faktor produksi dan pada efisiensi teknologi (terkait dengan penggunaan masukan dalam arti fisik). Jika output yang dihasilkan sama, maka proses yang terbaik adalah yang menggunakan masukan yang paling sedikit atau dengan kata lain, proses yang secara teknis paling efisien (Lipsey dan Steiner, 1986).

Besarnya efisiensi dapat dikur menggunakan $\mathrm{R} / \mathrm{C}$ ratio. $\mathrm{R} / \mathrm{C}$ adalah singkatan dari Return Cost Ratio atau dikenal sebagai perbandingan (nisbah) antara penerimaan dan biaya.

\section{METODE PENELITIAN}

\subsection{Tempat dan Waktu Penelitian}

Penelitian ini dilakukan di Kecamatan Tembilahan Kabupaten Indragiri Hilir. Lokasi penelitian dipilih di empat Kelurahan yaitu di Kelurahan Tembilahan Hilir, Kelurahan Tembilahan Kota, Kelurahan Pekan Arba, dan
Kelurahan Sungai Beringin. Pemilihan lokasi penelitian dilakukan secara purposive dengan pertimbangan bahwa wilayah tersebut memiliki banyak pedagang yang melakukan usaha pengolahan santan kelapa. Penelitian ini dilakukan pada bulan Januari sampai dengan bulan Maret 2017.

\subsection{Jenis dan Sumber Data}

Jenis data dalam penelitian ini adalah data primer dan data sekunder. Data Primer di peroleh melalui wawancara langsung kepada pedagang yang melakukan usaha pengolahan santan kelapa yang ada di Kecamatan Tembilahan meliputi identitas responden, produksi yang dihasilkan responden, pendapatan responden dan sebagainya. Data Sekunder diperoleh dari studi literatur yang relevan dengan penelitian ini seperti buku, skripsi, jurnal, internet,dan sebagainya. Data sekunder juga didapat dari instansi pemerintahan seperti kantor camat di Kecamatan Tembilahan dan data informasi lainnya yg berkaitan dengan penelitian.

\subsection{Populasi dan Sampel}

Penelitian ini menggunakan teknik sampling nonprobability sampling dengan jenis sampling jenuh yaitu teknik penentuan sampel bila anggota populasi digunakan sebagai sampel. Peneliti menggunakan teknik sampling ini karena jumlah populasi sebanyak 25 orang. Menurut Ridwan (2012:64), "Sampling jenuh ialah teknik pengambilan sampel apabila semua populasi digunakan sebagai sampel dan dikenal juga dengan istilah sensus". Dalam penelitian ini, jumlah populasi sebanyak 25 orang maka semua anggota populasi dijadikan 
sampel penelitian. Oleh karena itu, sampel yang diambil untuk penelitian ini sebanyak 25 orang.

\subsubsection{Biaya Produksi}

Dalam melakukan kegiatan usaha agroindustri ada biaya yang dikeluarkan yaitu biaya tetap (FC) dan biaya variabel (VC). Untuk mengetahui total biaya produksi secara matematis dirumuskan sebagai berikut :

$$
\mathrm{TC}=\mathrm{FC}+\mathrm{VC}
$$

Keterangan :

$\mathrm{TC}=$ Total Cost $(\mathrm{Rp} /$ Bulan $)$

$\mathrm{FC}=$ Fix Cost (Rp/Bulan)

$\mathrm{VC}=$ Variabel Cost (Rp/bulan)

Pendekatan pengeluaran atau biaya yang dilakukan selama satu kali produksi dalam sebulan adalah dengan mengakumulasikan pengeluaran selama satu kali produksi selama 30 hari. Asumsinya adalah pengeluaran yang dilakukan selama satu kali produksi selalu sama selama satu bulan.

\subsubsection{Penyusutan Alat}

Untuk menghitung biaya penyusutan alat dalam usahatani dihitung dengan metode garis lurus menurut Sinuraya (1985). Dengan rumus sbb:

$$
\mathrm{D}=\frac{\mathrm{C}-\mathrm{SV}}{\mathrm{UL}}
$$

Keterangan :

$\mathrm{D}=$ Nilai penyusutan alat

$\mathrm{C}=$ Harga beli alat

$\mathrm{SV}=$ Nilai sisa alat $(20 \% \times$ nilai beli)

$\mathrm{UL}=$ Masa pakai alat

\subsubsection{Penerimaan}

Penerimaan

usaha agroindustri adalah perkalian antara jumlah produksi yang diperoleh

\subsection{Metode Analisis Data}

dengan harga yang berlaku dipasar (Soekartawi, 1998). Jadi, penerimaan yang didapat pedagang santan kelapa adalah merupakan perkalian antara jumlah produksi santan kelapa dikali dengan harga yang berlaku dipasaran. Secara matematis rumusnya adalah sebagai berikut:

$$
\mathrm{TR}=\mathrm{Q} \times \mathrm{P}
$$

Keterangan :

$\mathrm{TR}=$ Total Revenue $(\mathrm{Rp} / \mathrm{Bulan})$

$\mathrm{Q}=$ Quantity $(\mathrm{Kg} /$ Bulan $)$

$\mathrm{P}=$ Price $(\mathrm{Rp} / \mathrm{Kg})$

Dengan rumus diatas maka hasil dari penjualan santan kelapa yang didapat merupakan fungsi dari jumlah produksi santan kelapa yang terjual dengan harga yang berlaku dipasar. Pendekatan yang dilakukan dalam penelitian ini adalah dengan cara melakukan wawancara selama 2-3 kali dalam seminggu. Asumsinya adalah pendapatan selama 2-3 kali wawancara diakumulasikan dalam 30 hari kerja atau sebulan kerja. Asumsi ini diambil karena selama penelitian hal-hal yang memicu lonjakan permintaan santan diabaikan (misal hari besar keagamaan), karena peneliti hanya ingin melihat pendapatan dalam permintaan harian.

\subsubsection{Keuntungan}

Keuntungan (Pendapatan bersih) adalah selisih lebih pendapatanatas beban sehubungan dengan usaha untuk memperoleh pendapatan tersebut selama periode tertentu.Dapat ditulis dengan rumus sebagai berikut:

$$
\pi=\mathrm{TR}-\mathrm{TC}
$$

Keterangan:

$\pi=$ Pendapatan Bersih (Rp/Bulan)

$\mathrm{TR}=$ Total Revenue (penerimaan usaha) (Rp/Bulan) 
$\mathrm{TC}=$ Total Cost (Biaya usaha)

(Rp/Bulan), (Soemarso,2004).

\subsubsection{Pendapatan Kerja Keluarga}

Menurut Hernanto (1991),

untuk menghitung pendapatan keluarga digunakan rumus sebagai berikut :

$$
\mathrm{PKK}=\pi+\mathrm{TKDK}+\mathrm{D}
$$

Keterangan :

PKK = Pendapatan kerja keluarga (Rp/bulan)

$\pi \quad=$ Keuntungan $(\mathrm{Rp} /$ Bulan$)$

TKDK = Upah tenaga kerja dalam

keluarga

$\mathrm{D} \quad=$ Penyusutan Alat

\subsubsection{Efisiensi}

Menurut Soekartawi (2002), analisis Return Cost (R/C) ratio merupakan perbandingan (ratio atau nisbah) antara penerimaan (revenue) dan biaya (cost). yang dikeluarkan dalam satu kali produksi. Untuk mengetahui efisiensi, maka rumus yang dipakai yaitu:

Keterangan :

$$
\text { Efisiensi }=\mathrm{R} / \mathrm{C}
$$

$\mathrm{R}=$ Penerimaan total usaha dagang (Rp/Bulan)

$\mathrm{C}=$ Total biaya yang dikeluarkan (Rp/Bulan)

Kriteria yang digunakan dalam penilaian efisiensi usaha adalah :

- R/C Ratio > 1, Usaha pengolahan santan kelapa dinyatakan layak.

- $\mathrm{R} / \mathrm{C}$ Ratio = 1, Usaha pengolahan santan kelapa dinyatakan berada pada titik impas.

- $\mathrm{R} / \mathrm{C}$ Ratio < 1, Usaha pengolahan santan kelapa tidak layak

\section{HASIL DAN PEMBAHASAN \\ 4.1. Teknik Pengolahan Santan Kelapa}

Santan atau adalah cairan putih kental yang dihasilkan dari kelapa yang diparut dan kemudian diperas bersama air. Santan mempunyai rasa lemak dan digunakan sebagai perasa yang menyedapkan masakan menjadi gurih. Kelapa (Cocos nucifera) adalah anggota tunggal dalam marga Cocos dari suku aren-arenan atau Arecaceae. Santan banyak digunakan dalam masakan Indonesia seperti opor ayam, rendang, gudeg, soto, sayur lodeh, nasi uduk atau dalam berbagai macam kari seperti kari daun singkong misalnya. Santan mempunyai rasa lemak, sehingga membuat rasa masakan menjadi lebih sedap dan gurih dengan aroma khas kelapa yang harum (adanya senyawa nonylmethylketone). Santan kelapa dapat diperoleh dari parutan kelapa segar di pasar atau dalam kemasan karton di pasar swalayan (Soekopitojo, 2014).

Masakan Indonesia tidak bisa lepas dari peran santan sebagai penguat rasa dan aroma, fungsinya membuat makan jadi lebih gurih dan nikmat, baik masakan ataupun kue kue manis. Proses pengolahan santan kelapa dapat dijelaskan sebagai berikut.

1. Cungkil buah kelapa dari batoknya menggunakan pisau pencungkil, kemudian kupas kulit ari dari buah kelapa agar bisa menghasilkan parutan yang putih dan bersih.

2. Agar buah kelapa lebih mudah untuk diparut rendam daging kelapa di dalam ember yang berisi air, sekaligus membersihkan daging kelapa agar bersih saat diparut. Selain menggunakan air dapat juga menggunakan air 
kelapa untuk membersihkan daging kelapa tersebut.

3. Parut daging kelapa yang sudah direndam menggunakan mesin parut kemudian hasil parutan diletakan diember.

4. Masukan hasil parutan ke dalam mesin press santan atau mesin pemeras santan kemudian aduk hasil parutan santan agar parutan masuk ke dalam mesin press santan.

5. Setelah hasil parutan di press menggunakan mesin, maka akan keluar santan kelapa di mesin tersebut kemudian santan dialirkan ke ember yang sudah diletakan saringan agar hasil santan kelapa tidak ada lagi ampas yang tersisa.

Kualitas kadar santan yang dihasilkan bervariasi tergantung kelapa yang dipilih. Umur kelapa yang telah dipanen juga akan berpengaruh pada rasa makanan. Kelapa yang baik digunakan untuk santan adalah kelapa yang tua agar hasil santan kelapa bagus. Sisa limbah hasil pengolahan santan kelapa berupa batok, ampas kelapa dan air kelapa tidak dibuang melainkan dijual sebagai penghasilan tambahan. Sisa limbah hasil produksi ini menambah penerimaan hasil jual santan dan menambah pendapatan dari pemilik usaha pengolahan santan kelapa.

\subsection{Analisis Usaha Pengolahan Santan Kelapa}

\subsubsection{Biaya Produksi}

Biaya produksi merupakan biaya yang dikeluarkan oleh pedagang santan kelapa selama melakukan kegiatan usahanya dimulai dari proses produksi hingga menghasilkan produk, yang meliputi biaya tetap dan biaya tidak tetap. Menurut Bambang (2006), biaya tetap adalah biaya yang relatif tetap jumlahnya, dan terus dikeluarkan walaupun produksi yang diperoleh banyak atau sedikit sedangkan biaya tidak tetap adalah biaya yang besar kecilnya dipengaruhi oleh produksi yang diperoleh.

Pada usaha pengolahan santan kelapa di Kecamatan Tembilahan biaya tidak tetap terdiri dari bahan baku yaitu kelapa, biaya pengemasan yaitu plastik, karet, asoy kecil, asoy sedang, dan asoy besar, kemudian biaya tmabahan yang terdiri dari bahan bakar dan sewa kios, yang terakhir yaitu biaya tenaga kerja yang terbagi menjadi dua yaitu biaya tenaga kerja dalam keluarga dan tenaga kerja luar keluarga sedangkan biaya tetap terdiri dari biaya penyusutan alat yang terdiri dari mesin pemarut, mesin pemeras, mesin engkol, parang, toples, ember, baskom, timbangan, pisau pencungkil, dan saringan. Rincian biaya produksi yang dikeluarkan dalam usaha pengolahan santan kelapa di Kecamatan Tembilahan dapat dilihat pada Tabel 1.

\section{a. Biaya Tidak Tetap}

Biaya tidak tetap adalah biaya yang sifatnya berubah - ubah tergantung dari besar kecilnya produksi yang dihasilkan (Soekartawi, 1995). Biaya variabel dalam dalam usaha pengolahan santan kelapa terdiri dari biaya bahan baku, biaya pengemasan, dan biaya tambahan. Pada Tabel 1 menunjukkan bahwa biaya tidak tetap dari usaha pengolahan santan kelapa di Kecamatan Tembilahan terdiri dari biaya bahan baku sebesar Rp. 23.418.000,00 bahan baku yaitu 
kelapa bulat diperoleh dari pedagang pengumpul kelapa. Biaya pengemasan yang terdiri dari plastik sebesar Rp. 820.800,00, karet sebesar Rp. 39.960,00, asoy kecil sebesar Rp. $89.760,00$, asoy sedang sebesar Rp. 104.600,00 dan asoy besar yaitu sebesar Rp. 97.920,00 , biaya bahan bakar sebesar Rp. 66.360,00, dan yang terakhir adalah biaya tenaga kerja sebesar Rp. 2.722.000,00. Maka dari itu dapat diketahui biaya tidak tetap sebesar Rp. 27.359.400,00 per perbulan produksi.
Menurut penelitian Juanda (2015) untuk proses kegiatan produksi santan memerlukan bantuan aliran listrik karena mesin parut dan mesin pemeras santan yang digunakan sudah modern dan memerlukan listik berbeda dengan penelitian di Kecamatan Tembilahan mesin parut dan mesin peras masih menggunakan mesin pembantu yaitu mesin diesel yang menggunakan bahan bakar.

Tabel 1. Analisis Biaya Produksi Usaha Pengolahan Santan Kelapa Per Bulan

\begin{tabular}{|c|c|c|c|c|}
\hline No. & Biaya & Satuan & Harga $(\mathrm{Rp})$ & Jumlah (Rp) \\
\hline \multirow[t]{11}{*}{1.} & Biaya Tidak Tetap & & & \\
\hline & a. Bahan Baku & Buah & $3.460,00$ & $23.418 .000,00$ \\
\hline & b. Biaya Pengemasan & & & \\
\hline & - $\quad$ Plastik & $\mathrm{Kg}$ & $27.360,00$ & $820.800,00$ \\
\hline & - $\quad$ Karet & $\mathrm{Kg}$ & $60.000,00$ & $39.960,00$ \\
\hline & - Asoy Kecil & Bungkus & $3.320,00$ & $89.760,00$ \\
\hline & - Asoy Sedang & Bungkus & $7.480,00$ & $104.600,00$ \\
\hline & - Asoy Besar & Bungkus & $9.040,00$ & $97.920,00$ \\
\hline & a. Bahan Bakar & $\mathrm{Rp}$ & & $66.360,00$ \\
\hline & b. Biaya Tenaga Kerja & $\mathrm{Rp}$ & & $2.722 .000,00$ \\
\hline & Jumlah & & & $27.359 .400,00$ \\
\hline \multirow[t]{4}{*}{2.} & Biaya Tetap & & & \\
\hline & a. Sewa Kios & $\mathrm{Rp}$ & & $329.800,00$ \\
\hline & b. Penyusutan Alat & $\mathrm{Rp}$ & & $545.759,56$ \\
\hline & Jumlah & & & $875.559,56$ \\
\hline \multicolumn{3}{|c|}{ Total } & & $28.234 .959,56$ \\
\hline
\end{tabular}

Sumber : Data primer diolah, 2017

\section{b. Biaya Tetap}

Biaya tetap adalah biaya yang relatif jumlahnya dan harus dikeluarkan walaupun produk yang dihasilkan banyak atau sedikit (Soekartawi, 1995). Pada Tabel 1 menunjukan bahwa biaya tetap terdiri dari biaya sewa kios
sebesarRp.329.800,00 dan biaya penyusutan alat per produksi sebesar Rp. 545.759,56. Sehingga dapat diketahui biaya tetap sebesar Rp. 875.559,56. Biaya penyusutan ini dihitung dari masing - masing peralatan yang ditentukan oleh banyaknya masing - masing alat 
yang digunakan dan umur ekonomisnya. Biaya penyusutan yang dimaksud disini adalah penyusutan alat-alat yang digunakan dalam pengolahan santan kelapa, terdiri dari mesin pemarut, mesin pemeras, mesing diesel, parang, toples, ember, baskom, timbangan, pisau pencungkil, dan saringan. Biaya penyusutan yang dihitung pada usaha ini dihitung dalam periode per bulan. Menurut penelitian yang dilakukan oleh Juanda (2015), biaya tetap merupakan biaya investasi awal usaha pengolahan santan kelapa seperti mesin parut dan mesin press karena paling sering digunakan dalam produksi.

\section{c. Total Biaya}

Menurut Soekartawi (1995), total biaya adalah keseluruhan biaya tetap ditambah dengan biaya tidak tetap. Biaya total merupakan biaya yang dikeluarkan pedagang santan kelapa secara keseluruhan. Dari tabel 1 memperlihatkan bahwa total biaya usaha pengolahan santan kelapa di daerah penelitian adalah rata-rata sebesar Rp. 28.234.959,56 per bulan, dimana jumlah biaya tetap rata-rata sebesar Rp.875.559,56 dan biaya tidak tetap sebesar Rp. 27.359.400,00 per bulan. Dapat disimpulkan bahwa biaya yang berkontribusi besar adalah biaya tidak tetap, hal ini dikarenakan biaya tidak tetap yang dikeluarkan beraneka ragam.
Penerimaan

usaha pengolahan santan kelapa di Kecamatan Tembilahan tersaji pada Tabel 2. Penerimaan usaha agroindustri adalah perkalian antara jumlah produksi yang diperoleh dengan harga yang berlaku dipasar (Soekartawi, 1998). Penerimaan yang diterima oleh pedagang santan kelapa adalah perkalian antara jumlah produksi santan kelapa, ampas kelapa, batok kelapa, dan air kelapa yang dihasilkan dengan harga santan kelapa, ampas kelapa, batok kelapa, dan air kelapa yang telah ditetapkan. Tabel 7 menunjukan bahwa penerimaan yang diperoleh yaitu rata- rata sebesar Rp.35.032.800,00 per bulan. Penerimaan diperoleh dari harga santan kelapa rata- rata $\mathrm{Rp}$. $15.480 / \mathrm{kg}$ dikalikan dengan jumlah produksi santan kelapa rata-rata yaitu $2.232 \mathrm{~kg}$ perbulan, ampas kelapa ratarata Rp.20.000,00 per karung dikalikan dengan jumlah ampas kelapa rata-rata 19,44karung perbulannya, batok kelapa rata-rata Rp.10.000,00 per karung dikalikan dengan jumlah batok kelapa rata rata 29,6 karung perbulan, dan air kelapa bila dijual per gelen rata-rata Rp. 2.000 dikalikan dengan jumlah air kelapa rata - rata 28,75 per gelen. Menurut penelitian Julianda (2015) rata-rata penerimaan yang didapat dari santan kelapadan batok di UD. Perasa Santan Murni Kental yaitu sebesar 43.290.000,00 per bulan.

\subsubsection{Penerimaan}

Tabel 2. Penerimaan Usaha Pengolahan Santan Kelapa di Kecamatan Tembilahan Per Bulan

\begin{tabular}{|c|l|r|r|r|}
\hline No. & \multicolumn{1}{|c|}{ Produksi } & $\begin{array}{c}\text { Jumlah } \\
\text { Produksi }\end{array}$ & Harga (Rp) & \multicolumn{1}{c|}{ Jumlah (Rp) } \\
\hline 1. & Santan Kelapa (kg) & 2.232 & $15.480,00$ & $34.339 .200,00$ \\
\hline 2. & Ampas Kelapa (karung) & 19,44 & $20.000,00$ & $388.800,00$ \\
\hline 3. & Batok Kelapa (karung) & 29,6 & $10.000,00$ & $296.000,00$ \\
\hline
\end{tabular}




\begin{tabular}{|r|r|r|r|r|}
\hline 4. & Air Kelapa (gelen) & 28,75 & $2.000,00$ & $57.500,00$ \\
\hline \multicolumn{3}{|c|}{ Total Penerimaan } & $35.033 .200,00$ \\
\hline
\end{tabular}

Sumber : Data primer diolah, 2017

\subsubsection{Keuntungan}

Komposisi penerimaan, keuntungan dan efisiensi usaha pengolahan santan kelapa di Kecamatan Tembilahan tersaji pada Tabel 3. Keuntungan yang diperoleh usaha pengolahan santan kelapa di Kecamatan Tembilahan merupakan selisih antara total penerimaan dengan total biaya yang dikeluarkan. Untuk mengetahui besarnya keuntungan pada usaha pengolahan santan kelapa di Kecamatan Tembilahan menunjukan bahwa keuntungan yang diperoleh sebesar Rp. 6.798.240,44 per bulan. Menurut Hernanto (1998), berhasil tidaknya usaha dapat dilihat dari besarnya pendapatan yang diperoleh dalam mengelola suatu usaha. Bagi pengusaha analisis ini membantu mereka dalam mengukur apakah kegiatan usaha mereka pada saat ini berhasil atau tidak.

Tabel 3. Komposisi penerimaan, keuntungan dan efisiensi usaha pengolahan santan kelapa di Kecamatan Tembilahan Per Bulan

\begin{tabular}{|c|l|r|}
\hline No. & \multicolumn{1}{|c|}{ Uraian } & \multicolumn{1}{|c|}{ Jumlah (Rp) } \\
\hline 1. & Total Biaya & $28.234 .959,56$ \\
\hline 2. & Penerimaan & $35.033 .200,00$ \\
\hline 3. & Keuntungan & $6.798 .240,44$ \\
\hline 4. & Pendapatan Kerja Dalam Keluarga & $8.688 .000,00$ \\
\hline 5. & RCR & 1,23 \\
\hline
\end{tabular}

Sumber : Data primer diolah, 2017

\subsubsection{Pendapatan Kerja dalam Keluarga}

Pendapatan kerja keluarga merupakan imbalan terhadap bunga harta sendiri, upah tenaga kerja keluarga, dan besarnya penghasilan yang di peroleh. Pada tabel 2 dapat dilihat bahwa jumlah pendapatan kerja dalam keluarga rata- rata sebesar Rp.8.688.000,00 per bulan. Pendapatan kerja keluarga diperoleh dari pendapatan bersih ditambah dengan upah tenaga kerja dalam keluarga dan penyusutan alat. Besarnya pendapatan tenaga kerja dalam keluarga pada usaha pengolahan santan kelapa dikarenakan banyaknya jumlah curahan tenaga kerja dalam keluarga yang digunakan pada usaha ini. Menurut Tohir (1983), keberhasilan atau kesuksesan usaha dapat dilihat daru sudut ekonomi yaitu besarnya penghasilan atau pendapatan kerja keluarga.

\subsubsection{Efisiensi}

Efisiensi usaha adalah gambaran layak tidaknya usaha tersebut dilakukan atau diusahakan. Menurut Soekartawi (2002), analisis Return Cost (R/C) ratio merupakan perbandingan (ratio atau nisbah) antara penerimaan (revenue) dan biaya (cost). yang dikeluarkan dalam satu kali produksi. Dari Tabel 3 dapat dilihat bahwa usaha pengolahan santan kelapa di daerah penelitian layak diusahakan, hal ini dapat dilihat dari besarnya $\mathrm{R} / \mathrm{C}$ yang diperoleh yaitu sebesar 1,23 yang berarti bahwa setiap Rp. 1 biaya 
yang dikeluarkan untuk usaha pengolahan santan kelapa akan menghasilkan pendapatan kotor atau penerimaan sebesar Rp. 1,23 dan pendapatan bersih atau keuntungan sebesar Rp. 0,23. Hal ini senada dengan penelitian yang dilakukan oleh Julianda (2015), nilai RCR yang diperoleh adalah sebesar 1,35 yang berarti usaha pengolahan santan kelapa menguntungkan.

\section{KESIMPULAN DAN SARAN}

\subsection{Kesimpulan}

1. Rata-rata penerimaan yang diperoleh sebesar Rp. 35.033.200,00per bulan, sedangkan rata-rata total biaya yang dikeluarkan adalah sebesar Rp. 28.234.959,56 per bulan sehingga diperoleh keuntungan rata-rata sebesar Rp.6.798.240,44per bulan.

2. Nilai efisiensi atau $\mathrm{R} / \mathrm{C}$ yang diperoleh adalah sebesar 1,23 yang berarti bahwa setiap Rp. 1 biaya yang dikeluarkan untuk usaha pengolahan santan kelapa akan menghasilkan pendapatan kotor atau penerimaan sebesar Rp. 1,23 dan pendapatan bersih atau keuntungan sebesar Rp. 0,23 . Hal ini menunjukan bahwa usaha pengolahan santan kelapa di Kecamatan Tembilahan efisien atau layak diusahakan.

\subsection{Saran}

1. Pedagang santan kelapa sebaiknya dapat meningkatkan produksi santan kelapa dikarenakan banyaknya permintaan pasar sehingga dapat meningkatkan pendapatan bagi pedagang santan kelapa.

2. Pedagang santan kelapa sebaiknya menjual air kelapanya daripada terbuang karena air kelapa dapat dimanfaatkan salah satunya sebagai bahan pembuatan nata de coco.

\section{DAFTAR PUSTAKA}

Badan Pusat Statistik. 2014. Inhil Dalam Angka. Tembilahan.

Badan Pusat Statistik. 2016. Kecamatan Tembilahan Dalam Angka. Tembilahan.

Bambang. 2006. Manajemen Sumber Daya Manusia. Sulita. Bandung.

Daniel. 2002. Pengantar Ekonomi Pertanian. Bumi Aksara. Jakarta.

Djatmiko, G. 1994. Daya Hasil Guna

Kelapa. Departemen Teknologi Hasil Pertanian Fatemata IPB. Bogor.

Hernanto, F. 1989. Ilmu Usaha Tani. PT. Penebar Swadaya. Jakarta.

,F. 1991. Ilmu Usaha Tani. PT. Penebar Swadaya. Jakarta

Julianda, A. 2015. Analisis Biaya Produksi Dan Pendapatan Usaha Kukur Santan Kelapa Pada UD. Peras Santan Murni Kental Di Pasar Peunayong Kota Banda Aceh. Universitas Syiah Kuala Darussalam. Banda Aceh.

Ketaren, S. 1986. Pengantar Teknologi Minyak dan Lemak Pangan. Cetakan Pertama. Jakarta : UI Press.

Lipsey et al, 1990. Pengantar Ilmu Ekonomi. Rineka Cipta. Jakarta. 
Mulyadi, 1995. Akuntan Biaya, Edisi kelima, Yogyakarta.

Santoso,U. 2000. Pengembangan Penelitian Pemanfaatan Kelapa Sebagai Bahan Pangan (Focus Of Research On Coconut As Food). Seminar Nasional Industry Pangan. Fakultas Teknologi Pertanian Universitas Gadjah Mada. Yogyakarta.

Sinuraya, S. 1985. Dasar - Dasar akuntansi. Fakultas Ekonomi Universitas Sumatera: Medan.

Soedjarwanto dan Riswan, 1994. Penyerapan Tenaga Kerja pada Industri Batu Bata di Kabupaten Dati II Banyumas. Skripsi S1
Fakultas Ekonomi UNSOED. Purwokerto.

Soekartawi. 1998. Analisis Usahatani. UI-Press, Jakarta.

.2002. Prinsip Dasar Ekonomi Pertanian: Teori Dana Aplikasinya. Raja Grafindo Persada, Jakarta.

Soekopitojo, $\quad$ S. 2014. http://www.kulinologi.c o.id/index1.php?view\&i $\underline{\mathrm{d}=940}$. Diakses pada tanggal 20 Maret 2017

Soemarso, 2004. Akuntansi Suatu Pengantar Edisi Lima. Salemba Empat. Jakarta.

Tohir, A.K. 1983. Seuntai Usahatani Indonesia. Bagian I. Bina Aksara. Jakarta. 